\title{
ERG wt Allele
}

National Cancer Institute

\section{Source}

National Cancer Institute. ERG wt Allele. NCI Thesaurus. Code C52865.

Human ERG wild-type allele is located in the vicinity of $21 \mathrm{q} 22.3$ and is approximately 280 $\mathrm{kb}$ in length. This allele, which encodes transcriptional regulator ERG protein, is involved in both the regulation of RNA polymerase II-directed transcription and the modification of local chromatin structure. Acute myelogenous leukemia of the subtype M2 is linked to the chromosomal translocation $\mathrm{t}(8 ; 21)(\mathrm{q} 22 ; \mathrm{q} 22)$, which involves this gene and the EWSR1 gene. Human myeloid leukemia is linked to the chromosomal translocation $t(16 ; 21)(p 11 ; q 22)$ of this gene with the FUS gene. 